\title{
Bibliography of Henry Dresser
}

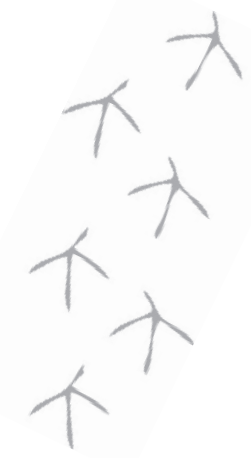

Dresser, H. E. (ed.) (1896-97). Society for the Protection of Birds. Educational Series leaflets. Published by the Society for the Protection of Birds at the Knowledge office, London:

No. 1. Owls by M. Sharpe (1896)

No. 2. Woodpeckers by Sir H. Maxwell (1896)

No. 3. Starling by O. V. Aplin (1897)

No. 4. Swallows by T. Southwell (1897)

No. 5. Kingfisher by Sir E. Grey (1897)

No. 6. Osprey by J. A. Harvie-Brown (1897)

No. 7. Dippers by W. L. Mellersh (1897)

No. 8. Nightjar by M. Sharpe (1897)

No. 9. Titmice by S. Buxton (1897)

No. 10. Kestrel by J. Kelsall (1897)

No. 11. Plovers by J. A. Pease (1897)

No. 12. Terns, or Sea Swallows by T. Southwell (1897)

No. 13. Wagtails by W. Warde Fowler (1897)

No. 14. Chough by J. A. Harvie-Brown (1897)

No. 15. The Jay by J. Cordeaux (1897)

No. 16. Skuas by T. E. Buckley (1897)

No. 17. Flycatchers by J. R. B. Masefield (1897)

No. 18. Nightingale by J. H. Allchin (1897)

No. 19. Gulls by H. Saunders (1897)

No. 20. Leaf-Warblers by H. E. Dresser (1897)

No. 21. Pipits by W. H. Hudson (1897)

No. 22. Skylark by F. A Fulcher (1897)

No. 23. Grebes by J. R. B. Masefield (1897)

No. 24. Common Buzzard by H. A. Macpherson (1898)

Priced at $1 \mathrm{~d}$ each, $3 \mathrm{~d}$ for a dozen, 1 s $6 \mathrm{~d}$ for 100; six assorted for $2 \mathrm{~d}$, twelve assorted for $4 \mathrm{~d}$; fifty for $1 \mathrm{~s}$.

\section{Reports of the 'Close-Time' Committee, British Association for the Advancement of Science}

British Association (1869). Applications for reports and researchers and involving grants of money. Report of the British Association for the Advancement of Science 1868: xlvii-xlviii. 
Close-Time Committee (1870). Report on the practicability of establishing a "closetime" for British animals. Report of the British Association for the Advancement of Science 1869: 91-6.

- (1871). Report on the practicability of establishing a "close-time" for indigenous animals. Report of the British Association for the Advancement of Science 1870: 13-14.

- (1872). Report on the practicability of establishing "a close-time" for indigenous animals. Report of the British Association for the Advancement of Science 1871: 197.

- (1873). Report of the committee ... appointed for the purpose of continuing the investigation on the desirability of establishing a "close time" for the preservation of indigenous animals. Report of the British Association for the Advancement of Science 1872: 320-1.

- (1874). Report of the committee ... appointed for the purpose of continuing the investigation on the desirability of establishing a "close time" for the preservation of indigenous animals. Report of the British Association for the Advancement of Science 1873: 346-8.

- (1875). Report of the committee ... appointed for the purpose of inquiring into the possibility of establishing a "close time" for the preservation of indigenous animals. Report of the British Association for the Advancement of Science 1874: 264-6.

- (1876). Report of the committee ... appointed for the purpose of inquiring into the possibility of establishing a "close time" for the preservation of indigenous animals, and for watching Bills introduced into Parliament affecting this subject. Report of the British Association for the Advancement of Science 1875: 184-5.

- (1877). Report of the committee ... appointed for the purpose of inquiring into the possibility of establishing a "close time" for the preservation of indigenous animals, and for watching Bills introduced into Parliament affecting this subject. Report of the British Association for the Advancement of Science 1876: 63-5.

- (1878). Report of the committee ... appointed for the purpose of inquiring into the possibility of establishing a "close time" for the preservation of indigenous animals. Report of the British Association for the Advancement of Science 1877: 207-8.

- (1879). Report of the committee ... appointed for the purpose of inquiring into the possibility of establishing a "close time" for indigenous animals. Report of the British Association for the Advancement of Science 1878: 146-9.

- (1879). Report of the committee ... appointed for the purpose of inquiring into the possibility of establishing a close time the protection of indigenous animals. Report of the British Association for the Advancement of Science 1879: 165.

- (1880). Report of the committee ... appointed for the purpose of inquiring into the possibility of establishing a close time for indigenous animals. Report of the British Association for the Advancement of Science 1880: 257.

\section{BoU Lists of British Birds}

Henry Dresser was a member of the Committees that produced the lists:

British Ornithologists' Union (Committee of) (1883). A List of British Birds, Compiled by a Committee of the British Ornithologists' Union. Van Voorst, London.

British Ornithologists' Union (Committee of) (1915). A List of British Birds, Compiled by a Committee of the British Ornithologists' Union. Second and revised edition. BOU, London. 


\section{Journal articles and books}

*Contains descriptions of new species or subspecies of birds

Dresser, H. E. (1863). Occurrence of a white Redwing in Norfolk. Zoologist (first series) 21: 8484 .

- (1865). Notes on the birds of Southern Texas. Ibis 7(3): 312-30; 7(4): 466-95.

- (1866). Notes on the birds of Southern Texas (concluded). Ibis 8(1): 23-46.

- (1866). Notes on the breeding of the Booted Eagle (Aquila pennata). Proceedings of the Zoological Society of London 1866(3): 377-80.

- (1867). List of birds noticed in East Finmark, with a few short remarks respecting some of them. By Ch. Sommerfeldt, parish priest of Naesseby. Translated and communicated by H. E. Dresser. Zoologist (second series) 2(April): 692-700; 2(June): 761-78.

- (1867). Notes on the breeding of the Booted Eagle (Aquila pennata) (communicated by the author and reprinted from the Proceedings of the Zoological Society of London). Zoologist (second series) 2(July): 803-7.

- (1869). Cuckow's eggs [letter]. Nature 1(8): 218.

- (1870). Exhibition of some eggs of the Little Gull (Larus minutus). Proceedings of the Zoological Society of London 1869(3): 530-1.

Sharpe, R. B. and H. E. Dresser (1870). On some new or little-known points in the economy of the Common Swallow (Hirundo rustica). Proceedings of the Zoological Society of London 1870(2): 244-9.

— and - (eds) (1870). Aves. Zoological Record 7.

- and - (1871). Notes on Lanius excubitor and its allies. Proceedings of the Zoological Society of London 1870(3): 590-600.

Dresser, H. E. (1871). Exhibition of rare European birds' eggs. Proceedings of the Zoological Society of London 1871(1): 102-4.

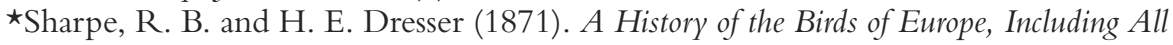
the Species Inhabiting the Western Palaeartic Region. Parts 1-9. Privately published, London. (Note that Sharpe assisted only with the first thirteen parts of this work; his name appeared as lead author on the paper covers of parts 1-17.)

Dresser, H. E. (1871). Exhibition of a specimen of Coccyzus americanus. Proceedings of the Zoological Society of London 1871(2): 299.

* Sharpe, R. B. and H. E. Dresser (1871). On a new species of Long-tailed Titmouse from Southern Europe. Proceedings of the Zoological Society of London 1871(2): 312-13.

^ — and - (1871). On two undescribed species of European birds (Picidae and Paridae). Annals and Magazine of Natural History (fourth series) 8: 436-7.

Dresser, H. E (1872). Exhibition of, and remarks upon, some skins and eggs of various species of Reguloides and Phylloscopus. Proceedings of the Zoological Society of London 1872(1): 25-6.

- (1872). Exhibition of some eggs of the Marbled Duck (Querquedula marmorata). Proceedings of the Zoological Society of London 1872(2): 605.

Sharpe, R. B. and H. E. Dresser (1872). A History of the Birds of Europe, Including All the Species Inhabiting the Western Palaearctic Region. Parts 10-13. Privately published, London. (Note that Sharpe assisted only with the first thirteen parts of this work, although his name appeared as lead author on the paper covers of parts 1-17.)

Dresser, H. E. (1872). A History of the Birds of Europe, Including All the Species Inhabiting the Western Palaearctic Region. Parts 14-15. Privately published, London. (Note 
that Sharpe assisted only with the first thirteen parts of this work, although his name appeared as lead author on the paper covers of parts 1-17.)

Dresser, H. E. (1873). Exhibition of, and remarks upon, the skins of various eagles (Aquila). Proceedings of the Zoological Society of London 1872(3): 863-5.

* - (1873). A History of the Birds of Europe, Including All the Species Inhabiting the Western Palaeartic Region. Parts 16-24. Privately published, London. (Note that Sharpe assisted only with the first thirteen parts of this work; his name appeared as lead author on the paper covers of parts 1-17.)

- (1873). Exhibition of birds from the Ural. Proceedings of the Zoological Society of London 1873(2): 473.

- (1873). On certain species of Aquila. Proceedings of the Zoological Society of London 1873(2): 514-17.

- (1874). Bird-catchers [letter to the Editor]. The Times, 12 March, p. 10, col. e.

* - (1874). A History of the Birds of Europe, Including All the Species Inhabiting the Western Palaearctic Region. Parts 25-34. Privately published, London.

- (1874). Notes on the Small Spotted Eagle of Northern Germany, Aquila maculata (Gm.). Annals and Magazine of Natural History (fourth series) 13: 373-5.

*- (1874). On a new species of Marsh-Warbler. Ibis 16(4): 420-2.

- and W. T. Blanford (1874). Notes on the specimens in the Berlin Museum collected by Hemprich and Ehrenberg. Ibis 16(4): 335-43.

*Blanford, W. T. and H. E. Dresser (1874). Monograph of the genus Saxicola, Bechstein. Proceedings of the Zoological Society of London 1874(2): 213-41.

*Dresser, H. E. (1875). A History of the Birds of Europe, Including All the Species Inhabiting the Western Palaearctic Region. Parts 35-46. Privately published, London.

- (1875). On the nest and eggs of Hypolais rama (Sykes). Proceedings of the Zoological Society of London 1874(4): 655-6.

- (1875). Notes on Severtzoff's 'Fauna of Turkestan' (Turkestanskie Jevotnie). Ibis 17(1): 96-112; 17(2): 236-50; 17(3): 332-2.

- (1875). Notes on the nest and egg of Hypolais caligata and on the egg of Charadrius asiaticus, Pall., together with remarks on the latter species and Charadrius veredus, Gould. Proceedings of the Zoological Society of London 1875(1): 97-8.

- (1875). Notes on Falco labradorus, Aud., Falco sacer, Forster, and Falco spadicus, Forster. Proceedings of the Zoological Society of London 1875(2): 114-17.

- (1875). Letter: On Carduelis caniceps. Ibis 17(3): 387.

- (1875). Letter: On Syvia rama and an occurrence of the Eastern Golden Plover in Britain. Ibis 17(4): 513-14.

- (1875). Letter: On the journal 'Sylvan'. Ibis 17(4): 515.

*- (1876). A History of the Birds of Europe, Including All the Species Inhabiting the Western Palaeartic Region. Parts 47-56. Privately published, London.

- (1876). Notes on Severtzoff's Fauna of Turkestan (Turkestanskie Jevotnie). Ibis 18(1): 77-94; 18(2): 171-91; 18(3): 319-30; 18(4): 410-22.

- (1876). Falco labradorus (Labrador Falcon). Ornithological Misellany 1: 185-91.

- (1876). Remarks on a hybrid between the Black Grouse and the Hazel Grouse. Proceedings of the Zoological Society of London 1876(2): 345-7.

* - (1876). On a new species of Broad-billed Sandpiper. Proceedings of the Zoological Society of London 1876(3): 674-5.

* - (1876). On a new species of Tetraogallus. Proceedings of the Zoological Society of London 1876(3): 675-7.

- (1876). Reprint of Eversmann's Addenda ad celeberrimi Pallasii Zoographiam Rossoasiaticam. Privately published, London.

- (1877). A History of the Birds of Europe, Including All the Species Inhabiting the Western Palaearctic Region. Parts 57-64. Privately published, London. 
- (1878). A History of the Birds of Europe, Including All the Species Inhabiting the Western Palaeartic Region. Parts 65-72. Privately published, London.

- (1879). A History of the Birds of Europe, Including All the Species Inhabiting the Western Palaeartic Region. Parts 73-6. Privately published, London.

- (1879). Translation from the Swedish of W. Meves, 1854, Oef. Ak. Förh. No. 8, On the change of colour in birds, through and irrespective of moulting. Zoologist (third series) 3(27): 81-9.

- (1880). A History of the Birds of Europe, Including All the Species Inhabiting the Western Palaeartic Region. Parts 77-82. Privately published, London.

- (1881). A List of European Birds Including All Species Found in the Western Palaearctic Region. Privately published, London.

- (1881). Exhibition of examples of Saxicola deserti and Picus pubescens - the former shot in Clackmannanshire, the latter in France. Proceedings of the Zoological Society of London 1881(2): 453.

- ('1881'=1882). A History of the Birds of Europe, Including All the Species Inhabiting the Western Palaeartic Region. Part 83-4 (final part). Privately published, London.

- (1883). Exhibition of, and remarks upon, the identity of Melittophagus boehmi and Merops dresseri. Proceedings of the Zoological Society of London 1882(4): 634.

- (1883). Exhibition of, and remarks upon, a specimen of Merops philippinus, stated to have been obtained near the Snook, Seaton Carew. Proceedings of the Zoological Society of London 1883(1): 1.

- (1884). Letter: On Otocorys brandti and Otocorys longirostris. Ibis 26(1): 116-18.

- (1884). Exhibition of, and remarks upon, some Ringed Pheasants from Corea. Proceedings of the Zoological Society of London 1883(4): 466.

- (1884). A Monograph of the Meropidae, or Family of the Bee-eaters. Parts 1-3. Privately published, London.

- (1885). Exhibition of, and remarks upon, specimens of Sylvia nisoria and Hypolais icterina, killed in Norfolk. Proceedings of the Zoological Society of London 1884(4): 477-8.

- (1885). The species of British-killed Spotted Eagles determined. Zoologist (third series) 9(102): 230-1.

- (1885). Bartram's Sandpiper, Little Bustard, and Hoopoe in Cornwall. Zoologist (third series) 9(102): 232.

- (1885). Letter: On Sylvia nisoria and S. melanocephala. Ibis 27(4): 453-4.

- (1885). A Monograph of the Meropidae, or Family of the Bee-eaters. Part 4. Privately published, London.

- (1886). On the Wren of St Kilda. Ibis 28(1): 43-5.

- (1886). Exhibition of, and remarks upon, specimens of the American Killdeer Plover (Aegialitis vocifera) and the Desert Wheater (Saxicola deserti) killed in Great Britain. Proceedings of the Zoological Society of London 1885(4): 835-6.

- (1886). A Monograph of the Meropidae, or Family of the Bee-eaters. Part 5. Privately published, London.

* - (1888). Exhibition of, and remarks upon, some specimens of a Titmouse obtained by Dr. Guillemard in Cyprus. Proceedings of the Zoological Society of London 1887(4): 563.

- (1888). Letter: On Syrrhaptes paradoxus in Jersey. Ibis 30(3): 376.

*- (1888). Exhibition, and remarks upon, an example of a new species of Shrike (Lanius raddei) from the Transcaspian District. Proceedings of the Zoological Society of London 1888(3): 291.

- (1889). Exhibition of, and remarks upon, some eggs of the Adriatic Black-headed Gull and the Slender-billed Gull obtained in Andalusia. Proceedings of the Zoological Society of London 1889(3): 316. 
- (1889). Notes on birds collected by Dr. G. Radde in the Transcaspian Region. Ibis 31(1): 85-92.

- (1890). Notes on birds collected by Dr. G. Radde in the Transcaspian Region. Ibis 32(3): 342-4.

- (1890). Three weeks on the Guadalquivir. The Naturalist 174: 17-38.

* - (1890). Notes on the Racquet-tailed Rollers. Annals and Magazine of Natural History (sixth series) 6: 350-1.

- (1890). Letter: On different forms of African Rollers. Ibis 32(3): 384-6.

- (1891). Notes on Eurystomus orientalis. Ibis 33(1): 99-102.

- (1891). On a collection of Birds from Erzeroom. Ibis 33(3): 364-70.

- (1891). Notes on some of the rarer Western Palaearctic birds. Ibis 33(3): 360-4.

- (1892). Friedrich Wilhelm Meves. Ibis 34(1): 191-2.

- (1892). Remarks on Lanius lahtora and its allies. Ibis 34(2): 288-93.

- (1892). Remarks on Lanius excubitor and its allies. Ibis 34(3): 374-80.

* - (1892). Remarks on the Palaearctic White-breasted Dippers. Ibis 34(3): 380-7.

- (1893). Letter: On omission in the synonymy of the Meropidae in the "Catalogue of birds in the British Museum'. Ibis 35(1): 151-2.

- (1893). On Acredula caudata and its allied forms. Ibis 35(2): 240-3.

- (1893). Notes on the synonymy of some Palaearctic birds. Ibis 35(3): 375-80.

*Salvadori, T. and H. E Dresser (1893). Exhibition and description of a new species of Acredula from Macedonia. Bulletin of the British Ornithologists' Club 1(4): 15. (Abstract dated 31 December 1892, but presumably not widely available until early 1893. Note, the original description was published under Dresser's name alone in error by the publishers: see Bulletin of the British Ornithologists' Club 1(5): 23(n).)

^Dresser, H. E. (1893). Exhibition and description of Cryptolopha xanthopygia obtained from the Island of Palawan by Mr J. Whitehead. Bulletin of the British Ornithologists' Club 1(6): 31.

- (1893). A Monograph of the Coraciidae, or Family of the Rollers. Privately published, Farnborough.

- (1894). Remarks on some specimens of Central-Asiatic Shrikes. Ibis 36(3): 384-5.

- (1895). Notes on several rare Palaearctic Birds. Proceedings of the Zoological Society of London 1895(2): 311-12.

- (1895). Supplement to A History of the Birds of Europe, Including All the Species Inhabiting the Western Palaearctic Region. Parts 1-6. Privately published, London.

- (1896). Supplement to A History of the Birds of Europe, Including All the Species Inhabiting the Western Palaeartic Region. Parts 7-9. Privately published, London.

- (1897). Pallas's Willow Warbler shot at Cley-next-the-sea, Norfolk. Proceedings of the Zoological Society of London 1896(4): 856.

- (1897). Recent additions to the British Avifauna. Zoologist (fourth series) 1(667): $5-7$.

- (1897). Notes on Pallas's Willow Warbler and some other rare European Warblers. Transactions of the Norfolk and Norwich Naturalists' Society 6: 280-90.

— (1897). Obituary notice of Heinrich Gätke. Zoologist (fourth series) 1(669): 139-40.

- (1897). Osprey in Dorset. Zoologist (fourth series) 1(677): 508.

- (1898). Rare partridges in Leadenhall Market. Zoologist (fourth series) 2(683): 215.

- and E. Delmar Morgan (1899). On new species of birds obtained in Kan-su by M. Berezovsky. Ibis 41(2): 270-6.

Dresser, H. E. (1901). Exhibition of specimens of 'three-colour' printing. Bulletin of the British Ornithologists' Club 11(79): 59.

- (1901). On variation in plumage of Emberiza citrinella (exhibition, on behalf of 
E. S. Montagu, of a red-throated variety obtained near Cambridge). Bulletin of the British Ornithologists' Club 11(80): 66.

- (1901). Notice of reproductions of an illustration of the Labrador Falcon by Joseph

Wolf. Zoologist (fourth series) 5(724): 400.

- (1901). On some rare or unfigured Palaearctic birds' eggs. Ibis 43(3): 445-9.

- (1901). On variation in plumage of Emberiza citrinella (further exhibition, on behalf of E. S. Montagu, of a red-throated variety obtained near Cambridge). Bulletin of the British Ornithologists' Club 11(81): 69-70.

- (1901). Local variation in Grouse [letter]. The Field 98(2552, 23 November): 829.

- (1902). On some rare Palaearctic birds' eggs. Ibis 44(2): 177-80.

- (1902). Letter: On Emberiza erythrogenys, Brehm. Ibis 44(2): 352.

*- (1902). On a new pheasant from Japan. Ibis 44(4): 656-7.

- (1902). Exhibition of eggs of rare species of birds, collected by Mr Zarudny in Transcaspia and E. Persia. Bulletin of the British Ornithologists' Club 12(90): 83.

- (1902). A Manual of Palaeartic Birds. Part 1. Privately published, London.

- (1902). Exhibition of eggs of Falco altaicus and Parus cypriotes. Bulletin of the British Ornithologists' Club 13(91): 18.

- and H. Trueman Wood (1902). The reproduction of colours by photography. Nature 67(1728): 127-9.

Dresser, H. E. (1903). Exhibition of eggs of rare Palaearctic birds [collected in Transcaspia by Zarudny and sent by him]. Bulletin of the British Ornithologists' Club 13(95): 50.

- (1903). A Manual of Palaeartic Birds. Part 2. Privately published, London.

- (1903). On some rare or unfigured Palaearctic birds' eggs. Ibis 45(1): 88-9.

- (1903). Notes on the synonymy of some Palaearctic birds. Ibis 45(1): 89-91.

- (1903). Birdsnesting in lower Hungary, Bosnia, \&c. The Field 101(2615, 7 February): 222.

- (1903). On some rare and unfigured Palaearctic birds' eggs. Ibis 45(3): 404-7.

- (1904). Breeding of the Knot on the Taimyr Peninsula. Bulletin of the British Ornithologists' Club 14(102): 32. (Meeting date 16 December 1903, abstract dated 29 December, but probably not widely available until early 1904.)

- (1904). On some rare or unfigured Palaearctic birds' eggs. Ibis 46(1): 106-12.

- (1904). On some rare and unfigured Palaearctic birds' eggs. Ibis 46(2): 280-3.

- (1904). On some rare or unfigured Palaearctic birds' eggs. Ibis 46(4): 485-9.

- (1904). Exhibition of nest and eggs of Rose-finches. Bulletin of the British Ornithologists' Club 15(110): 26.

- (1904). On the late Dr. Walter's Ornithological researches in the Taimyr Peninsular. Ibis 46(2): 228-35.

- (1905). Eggs of the Birds of Europe, Including All the Species Inhabiting the Western Palaeartic Area. Parts 1-2. Privately published, London.

- (1905). Exhibition of some birds' eggs from Persia. Bulletin of the British Ornithologists' Club 15(112): 38

- (1905). Exhibition of types of three new species from Tibet. Bulletin of the British Ornithologists' Club 15(112): 38.

- (1905). Exhibition of the parent bird, nest and eggs of Cossypha gutturalis. Bulletin of the British Ornithologists' Club 15(116): 76.

* - (1905). Descriptions of three new species of birds obtained during the recent expedition to Lhassa. Proceedings of the Zoological Society of London 1905(1): 54-5.

- (1905). An oological journey to Russia. Ibis 47(2): 149-58.

- (1905). On some rare or unfigured Palaearctic birds' eggs. Ibis 47(4): 525-7.

- (1905). Exhibition of some Tibetan eggs. Bulletin of the British Ornithologists' Club 16(120): 38. 
- (1905). On Mr. Buturlin's discovery of the breeding-place of Ross's Rosy Gull in NE Siberia. Bulletin of the British Ornithologists' Club 16(120): 41.

- (1906). Exhibition of eggs of Ross's Rosy Gull. Bulletin of the British Ornithologists' Club 16(125): 97.

- (1906). Eggs of the Birds of Europe, Including All the Species Inhabiting the Western Palaearctic Area. Parts 3-6. Privately published, London.

- (1906). On some Palaearctic birds' eggs from Tibet. Ibis 48(2): 337-47.

- (1906). Note on the egg of Ross's Rosy Gull. Ibis 48(3): 610-11.

- (1906). Letters on the taking of the eggs of the Great Skua in Iceland. Ibis 48(3): 611-12; 48(4): 737-8.

- (1906). Obituary of Canon Henry Baker Tristram, D.D., F.R.S., etc. etc. Zoologist (fourth series) 10(778): 155-6.

- (1907). On behalf of Mr. S. A. Buturlin exhibited and made remarks on examples of nine species of Siberian birds. Bulletin of the British Ornithologists' Club 19(130): 43.

- (1907). Exhibition of young in down of Rhodostethia rosea, Tringa maculata, and Limosa novae zealandiae from N. E. Siberia. Bulletin of the British Ornithologists' Club 19 (135): 109.

- (1907). On some rare Palaearctic birds' eggs. Ibis 49(2): 322-4.

- (1907). On the breeding-habits of the Rosy Gull and the Pectoral Sandpiper by S.

A. Buturlin (communicated by H. E. Dresser). Ibis 49(4): 570-3.

- (1907). Eggs of the Birds of Europe, Including All the Species Inhabiting the Western Palaearctic Area. Parts 7-10. Privately published, London.

— (1907). Obituary of Professor A. Newton. Zoologist (fourth series) 11(793): 272-3.

- (1908). Exhibition of, and remarks on, various species of birds. Bulletin of the British Ornithologists' Club 21(140): 52-3.

- (1908). Exhibition of eggs of Hypolais icterina, H. caligata, Motacilla ocularis, Carpodacus erythrinus, Emberiza leucocephala, and Pratincola maura. Bulletin of the British Ornithologists' Club 21(143): 98-9.

- (1908). Eggs of the Birds of Europe, Including All the Species Inhabiting the Western Palaearctic Area. Parts 11-16. Privately published, London.

- (1908). Further notes on rare Palaearctic birds' eggs. Ibis 50(3): 486-90.

— (1908). On the Russian Arctic Expedition of 1900-1903. Ibis 50(3): 510-17; 50(4): 593-9.

- (1908). Baron Toll's Russian Arctic Expedition. The Field 112(2911, 10 October): 630-1.

- (1908). Exhibition of some rare eggs, viz. Lampronetta fischeri, Brandt, and Phylloscopus viridianus. Bulletin of the British Ornithologists' Club 23(146): 39.

- (1908). An old record of the Little Bunting in Essex. British Birds 1(12): 385.

- (1909). Eggs of the Birds of Europe, Including All the Species Inhabiting the Western Palaearctic Area. Parts 17-20. Privately published, London.

- (1909). Exhibition of two examples of a rare wader (Pseudoscolopax taczanowskii, Verr.) from Western Siberia [together with egg]. Bulletin of the British Ornithologists' Club 23(149): 60-1.

- (1909). On the occurrence of Pseudoscolopax taczanowskii in Western Siberia. Ibis 51(3): 418-21.

- (1909). On the males of the White-spotted Bluethroat. Ibis 51(3): 561.

- (1910). Exhibition of eggs of the Slender-billed Curlew (Numenius tenuirostris), the Siberian form of the Common Curlew (N. lineatus), and Swinhoe's Snipe (Gallinago megala). Bulletin of the British Ornithologists' Club 25(156): 38-9.

- (1910). Eggs of the Birds of Europe, Including All the Species Inhabiting the Western Palaearctic Area. Parts 21-4. Privately published, London. 
- (1910). Proceedings of the Fifth International Congress of Ornithologists. Ibis 52(4): 710-13.

\section{Notices about Dresser's collection}

Anon. (1899). Notice of the acquisition of Mr H. E. Dresser's collection of birds by the Manchester Museum. Ibis 41(4): 663-4.

Anon. (1899). Sale of H. E. Dresser's ornithological collection. Zoologist (fourth series) 3(698): 384.

Anon. (1899) Notice of the acquisition of H. E. Dresser's collection by Manchester Museum. Science Gossip (new series) 6(64): 119.

Anon. (1912). The Dresser collection of birds' eggs. Ibis 54(1): 215-16.

Anon. (1931). The oological collection at Cambridge. Ibis 73(2): 355-7.

Brewer, T. M. (1877). A run through the museums of Europe. Popular Science Monthly 11(25): 472-81.

\section{Biographical notices}

Anon. (1905). Portraits of European ornithologists. Condor 7(3): 67.

Evans, A. H. (ed.) (1909). Henry Eeles Dresser. In Biographical notices of the original members of the British Ornithologists' Union, of the principal contributors to the first series of 'The Ibis' and of the officials, pp. 219-20 (and photograph). Ibis 50, Supplement 1 (Jubilee Supplement): 71-232.

Anon. (1910). International Ornithological Congress. Bird Notes and News 4 (2): 13.

\section{Obituaries of Dresser}

Anon. (1915). 'Mr. H. E. Dresser'. The Times, 6 December, p. 6, col. d.

Anon. (1915). Obituary - Mr. Henry Eeles Dresser. Bird Notes and News 6(8): 121-1.

Anon. (1915). Obituary - H. E. Dresser. Nature 96(2406): 403.

Anon. (1916). Obituary - H. E. Dresser. Ibis 58(2): 340-2.

Anon. (1916). Obituary notice - Henry Dresser. Ети 15: 267.

Anon. (1917). Obituary: Dresser Henry Eeles 1838-1915. Aquila 23: 597-9.

Buturlin, S. A. (1916). [Henry E. Dresser - obituary.] Nasha Okhota [Our Hunting] 1916(3): 3-4 (in Russian).

Buturlin, S. A. (1916). [Henry Eeles Dresser - obituary.] Messager Ornithologique [Ornitologiskii Vyestnik] 7: 71-4 (in Russian).

Fortune, R. (1916). In memoriam: Henry Eeles Dresser. The Naturalist 708, 485 of new series: $25-6$.

Harting, J. E. (1915). Obituary - Henry Dresser. Field, 11 December, p. 978.

Rothschild, W. (1916). Henry Eeles Dresser [obituary]. British Birds 9(8): 194-6.

Stone, W. (1916). Notes and news - obituary of Henry Eeles Dresser. Auk 33(2): 232. 